\title{
ERGONOMICS, WORK AND HEALTH
}


This book is dedicated to my students: past, present and future

"The reasonable man adapts himself to the world: the unreasonable one persists in trying to adapt the world to himself. Therefore all progress depends on the unreasonable man."

Man and Superman, George Bernard Shaw

"We are all in the gutter, but some of us are looking at the stars."

Lady Windermere's Fan, Oscar Wilde 


\title{
ERGONOMICS, WORK AND HEALTH
}

\author{
Stephen Pheasant
}

Consulting Ergonomist

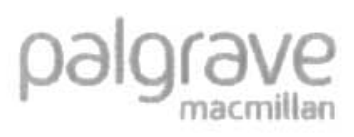




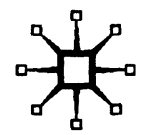

\section{O S.T. Pheasant 1991}

All rights reserved. No reproduction, copy or transmission of this publication may be made without written permission.

No paragraph of this publication may be reproduced, copied or transmitted save with written permission or in accordance with the provisions of the Copyright, Designs and Patents Act 1988, or under the terms of any licence permitting limited copying issued by the Copyright Licensing Agency, 90 Tottenham Court Road, London W1T 4LP.

Any person who does any unauthorised act in relation to this publication may be liable to criminal prosecution and civil claims for damages.

The author has asserted his right to be identified as the author of this work in accordance with the Copyright, Designs and Patents Act 1988.

Published by

PALGRAVE MACMILLAN

Houndmills, Basingstoke, Hampshire RG21 6XS and

175 Fifth Avenue, New York, N. Y. 10010

Companies and representatives throughout the world

PALGRAVE MACMILLAN is the global academic imprint of the Palgrave Macmillan division of St. Martin's Press, LLC and of Palgrave Macmillan Ltd. Macmillan ${ }^{\oplus}$ is a registered trademark in the United States, United Kingdom and other countries. Palgrave is a registered trademark in the European Union and other countries.

ISBN 978-0-333-48998-7 ISBN 978-1-349-21671-0 (eBook)

DOI 10.1007/978-1-349-21671-0

This book is printed on paper suitable for recycling and made from fully managed and sustained forest sources.

A catalogue record for this book is available from the British Library. 


\section{Contents}

Foreword

viii

Acknowledgements $\quad x$

Prologue 1

Chapter 1 Introduction 3

What is Ergonomics? 3

Ergonomics, Work and Health 5

Ergonomics and Design $\quad 13$

Ergonomics and Economics $\quad 15$

Chapter 2 The Physiology of Work 24

Bioenergetics of Exercise $\quad 24$

Static and Dynamic Work $\quad 32$

Physical Workload: Cardiovascular Demands 33

Biomechanics of Muscle $\quad 38$

$\begin{array}{ll}\text { Strength } & 43\end{array}$

Muscle Pain and Dysfunction $\quad 48$

Appendix: Anatomical Terminology $\quad 54$

Chapter 3 Back Pain at Work 57

Epidemiology: Some Definitions

Low Back Pain $\quad 58$

Work-related Risk Factors $\quad 65$

Personal Risk Factors $\quad 72$

$\begin{array}{ll}\text { Summary } & 75\end{array}$

Chapter 4 Repetitive Strain Injuries 77

RSI: The Australian Epidemic $\quad 79$

Neck and Shoulder Pain $\quad 81$

Disorders of the Elbow, Forearm, Wrist and Hand 88

Some Other Conditions $\quad 96$ 
$\begin{array}{lll}\text { Chapter } 5 & \text { Posture } & 98\end{array}$

$\begin{array}{ll}\text { Standing } & 100\end{array}$

Sitting $\quad 104$

$\begin{array}{ll}\text { Lying } & 106\end{array}$

$\begin{array}{ll}\text { Squatting } & 107\end{array}$

$\begin{array}{ll}\text { Working Posture } & 107\end{array}$

$\begin{array}{lll}\text { Chapter } 6 \text { Work Design } & 116\end{array}$

$\begin{array}{ll}\text { The Systems Approach } & 116\end{array}$

Task Demands and Working Capacity 118

$\begin{array}{lr}\text { Anthropometrics } & 122\end{array}$

$\begin{array}{ll}\text { Working Efficiency } & 127\end{array}$

Job Design: The Broader Issues $\quad 134$

Chapter 7 Stress, Fatigue and the Working Environment 139

$\begin{array}{ll}\text { The Semantics of Stress } & 140\end{array}$

A Taxonomy of Stress $\quad 141$

Stress, Arousal and Performance $\quad 142$

$\begin{array}{lr}\text { Work Stress } & 148\end{array}$

Mental Workload $\quad 153$

$\begin{array}{lr}\text { Fatigue } & 156\end{array}$

$\begin{array}{ll}\text { Working Hours } & 161\end{array}$

Chapter 8 Shiftwork 165

Circadian Rhythms 166

The Effects of Shiftwork on Health and Well-being 169

The Design of Shiftwork 173

Chapter 9 Accidents, Errors and Interfaces 176

Accident Proneness $\quad 177$

Human Error $\quad 181$

$\begin{array}{ll}\text { Error Ergonomics } & 185\end{array}$

Chapter 10 Visual Work 196

$\begin{array}{ll}\text { Light and Vision } & 196\end{array}$

Visual Displays $\quad 201$

The Visual Environment 204

$\begin{array}{ll}\text { Eyestrain } & 210\end{array}$ 
Chapter 11 The Ergonomics of Seating 212

The Physiology of Comfort $\quad 212$

Seat Design $\quad 214$

Seating and Back Pain $\quad 222$

The Office Desk 226

Office Chairs 228

Adjusting the Workstation $\quad 229$

Chapter 12 Working with Computers 231

VDUs and Health 231

Workstation and Task Design 236

$\begin{array}{ll}\text { Pausgymnastik } & 247\end{array}$

Chapter 13 Driving 253

Driving Posture and Workstation Layout 253

Dynamic Loading 256

Vibration $\quad 257$

Chapter 14 Hand Function and Tool Design 261

Repetitive Manipulative Tasks 261

Hand Function 263

Tools and Handles $\quad 268$

Vibration Syndrome $\quad 274$

Chapter 15 Lifting and Handling 277

Epidemiology $\quad 277$

The Mechanics of Lifting 278

$\begin{array}{ll}\text { Selection } & 287\end{array}$

Training $\quad 289$

Work Design 301

Maximum Permissible Loads $\quad 306$

Chapter 16 Clinical Ergonomics $\quad 320$

Checklist: Thirty Ergonomic Questions 321

Back Schools $\quad 323$

Ageing and Disability $\quad 324$

Epilogue: Macroergonomics 329

References 331

Index 355 


\section{Foreword}

It is a brave man who rises from the trenches of his own discipline and moves to occupy the high ground of an ally as they advance on the broad front of Knowledge.

As its title implies, this book is intended to place Ergonomics firmly in the clinical setting in which it is very much needed; it will stand with a regrettably small number of other texts as requisite reading for all in Occupational Health. It follows logically from the author's recent Bodyspace, itself a considerable help to occupational physicians.

As an examiner in the Associateship examination of the Faculty of Occupational Medicine, one of my most important, and rewarding, tasks is to read the journals of the candidates encompassing a four-week period of their working lives. It is encouraging to see ergonomic concepts and ideas increasingly featured; to see a recognition of ergonomic problems and a need to seek precisely the solutions this book is designed to offer.

The fact that patterns of work, not just "industry", have changed world-wide in the last few decades illustrates that we have substituted one set of ergonomic problems for another, no less intractable if not scientifically analysed; the computer instead of the blast furnace; the human errors of Chernobyl, Three Mile Island and Zeebrugge instead of mining disasters.

The whole gamut of the work environment is covered and the author does not evade the Byzantine problems of back pain, the Waterloo of so many aspiring authors.

Many who are invited to contribute a foreword must cry "Why me?" As I write, the travails of the Channel Tunnel construction appear in the press and on our TV screens weekly and the giant machines which grind their way towards each other in climactic consummation are awe-inspiring to behold. Years ago I told the author of the intense rivalry between mining machinery manufacturers in the Soviet Union and Western Europe. Nowhere was this more intense than in tunnelling, where vast prototypes were claimed to advance through strata at a rate undreamt of. The acme was reached by one company, the last word, and duly demonstrated. Unfortunately the sole operator was positioned at the front of the machine and disappeared into the tunnel in a cloud of noise and dust. No, he did NOT turn up in Australia and, YES, the design was radically modified. The upshot was the development of a team of ergonomists who cast a critical eye over all prototypes offered to the British mining industry. The resultant modifications and improvements had much to do with the fact that the British coalmining industry has the 
best safety record in the world, not due solely to good ergonomics, but in which our discipline has paid a vital part.

The moral is, never tell your best stories to your best friends in case you are asked to write a foreword. But bear this story in mind as you read this book....

Dr Roy Archibald

October, 1990 


\section{Acknowledgements}

Many of the ideas which go into a book like this surface for the first time in conversation with friends and colleagues-in ways which do not necessarily lend themselves to the normal conventions of academic citation. I have discussed the central topics of this book, at length and over the years, with David Stubbs, Peter Buckle and their colleagues at the Robens Institute-to the extent that we have probably all long since forgotten who said what first. I am particularly indebted to Sheila Lee for introducing me to the fascinating world of osteopathy. Anne-Marie Potts, Jackie Nicholls and Fiona Turner have also given me the benefits of their clinical knowledge; and conversations with John Long have helped me tighten up the nuts and bolts of my conceptual frameworks. The story of the chemical plant, with which I commence this book, was told to me originally by Mike Gray of the HSE. To all these people and to anybody else I have unconsciously plagiarized I extend my thanks.

Thanks are also due to David Sanchez and Andrew Pinder, who helped with the illustrations, and Pamela Dale, who patiently typed my endless revisions of the manuscript; and to my "other publishers", Taylor and Francis Ltd, for generously allowing me to reproduce so many illustrations from Bodyspace (1986). 